\title{
Pengaruh penggunaan pembelajaran student facilitator and explaining dan minat terhadap hasil belajar siswa
}

\author{
Witra Alti ${ }^{1}$, Helmi Hasan ${ }^{2}$ \\ ${ }^{1}$ Program Pasca Sarjana, Universitas Negeri Padang \\ ${ }^{2}$ Universitas Negeri Padang
}

\begin{abstract}
This research aims to find out: (1) the outcome of the different learning between student taught by using student facilitator and explaining (SFE) and conventional model and learning outcome by looking from learning interest. (2) the influence of interaction between SFE with conventional models. This research is experimental research (quasi-experiment) with an ANOVA $2 x 2$ factorial design. The outcome of research is (1) there is difference of student learning outcome between student taught by SFE with conventional models, (2) the student outcome who has hight interest taught with SFE hight more than conventional models, (3) the student outcome learning who has low interest taught with SFE hight more than with conventional models, (4) there are not an in influence of interaction between student taught student SFE with conventional models.
\end{abstract}

Keyword: Model student facilitator and explaining, convensional, interest learning (hight-low), student learning outcome

\section{PENDAHULUAN}

Mata pelajaran Ilmu Pengetahuan Sosial atau IPS merupakan salah satu mata pelajaran yang diajarkan di tingkat satuan pendidikan Indonesia. Wirdawati (2017:8) menjelaskan bahwa Ilmu Pengetahuan Sosial (IPS) merupakan intergrasi dari berbagai cabang ilmu sosial seperti: Sosiologi, Sejarah, Geografi, Ekonomi, Politik, Hukum dan Budaya. Mata pelajaran IPS dapat dipahami sebagai mata pelajaran di sekolah yang dirumuskan atas dasar realitas dan fenomena sosial yang di organisasikan dengan pendekatan interdisiplin, multidisiplin atau transdisiplin dari ilmu-ilmu sosial dan humaniora (Wirdawati 2017: 19). Ruang lingkup IPS adalah prilaku sosial, ekonomi, dan budaya manusia di masyarakat dalam konteks ruang dan waktu mengalami perubahan.

Pembelajaran IPS mengharapkan siswa untuk memahami konsep, mengaplikasikan teori, dapat berfikir logis dan kritis, ingin tahu, inquiri, kreatif, inovatif kolaboratif dan terampil menyelasaikan masalah serta dapat mengaplikasikan dalam kehidupan masyarakat. Hasil dari pembelajaran IPS akan terlihat pada hasil belajar. 
Hasil belajar menurut Sudjana (2009:3) menjelaskan bahwa terjadi perubahan tingkahlaku sebagai hasil belajar dalam pengertian yang lebih luas mencakup bidang kognitif, efektif dan psikomotorik. Namun wawancara yang dilakukan 5 Agustus 2019 dengan salah satu guru bidang studi IPS, rata-rata hasil belajar siswa dari beberapa kelas terlihat masih ada yang berada dibawah standar kelulusan. Rendahnya nilai belajar siswa dipengaruhi oleh minat belajar siswa yang terlihat rendah. Hal ini dilihat dari kurangnya keaktifan siswa selama proses pembelajaran. Rendahnya keaktifan belajar siswa diduga dipengaruhi oleh guru lebih mendominasi proses belajar dan juga kurang mengikut sertakan siswa untuk mengeksplore lebih banyak materi pembelajaran secara mandiri. Kemungkinan akan terjadi kebosanan yang dirasakan siswa. Terkadang tidak seluruh siswa yang berkonsentrasi mendengarkan penjelasan dari guru tentang materi-materi yang disampaikan, beberapa siswa tersebut bisa saja menganggu siswa yang lainnya.

Slameto (2010:54) menyatakan bahwa, faktor-faktor yang mempengaruhi belajar dapat digolongkan menjadi dua golongan, yaitu faktor internal dan faktor eksternal. Secara internal diduga bahwa minat belajar siswa kurang selama proses pembelajaran. Kurangnya minat akan berdampak pada kurangnya keaktifan siswa dalam proses belajar. Minat menurut Syah (2005: 151) menjelaskan minat secara sederhan bahwa minat berarti kecendrungan dan kegairahan yang tinggi atau keinginan yang besar terhadap sesuatu. Crow and Crow dalam Djaali (2008: 121) juga mengatakan bahwa minat berhubungan dengan gaya gerak yang mendorong seseorang untuk mengahadapi atau berurusan dengan orang, benda, kegiatan, pengalaman yang dirangsang oleh kegiatan itu sendiri. Faktor ekternal yang pempengaruhi yaitu penggunaan strategi pembelajaran yang sering berulangulang selama kegiatan pembelajaran.

Berdasarkan masalah yang dihadapi maka dari itu diperlukan solusi yang dapat membantu permasalahan tersebut. Model pembelajaran menurut Joyce \& Weil dalam Rusman (2011:133) merupakan suatu rencana atau pola yang dapat digunakan untuk membentuk kurikulum (rencana pembelajaran jangka panjang), merencanakan bahan-bahan pembelajaran dan membimbing pembelajaran dikelas atau yang lain. Hal ini bisa dikatan bahwa model pembelajarn mengarahkan guru dan siswa selama proses pembelajaran, guru berperan untuk menentukan model pembelajaran yang akan digunakan. Hal ini diperkuat dengan apa yang dijelaskan oleh Rusman (2011: 133) bahwa model pembelajaran dapat dijadikan pola pilihan, artinya para guru boleh memilih model pembelajaran yang sesuai dan efesien untuk mencapai tujuan pendidikanya.

Salah satu model pembelajaran yang mengaktifkan siswa dalam belajar salah satunya menurut Hamzah B. Uno dan Nurdin Mohamad (2012:88) yaitu model student fasilitator and eksplaining. Model pembelajaran student facilitator and explaining merupakan model pembelajaran dimana siswa/ peserta mempresentasikan ide/ pendapat pada rekan peserta lainya. Strategi dalam model student facilitator and explaining merupakan penyajian materi ajar yang diawali dengan penjelasan secara terbuka, memberi kesempatan kepada siswa untuk menjelaskan kembali kepada rekan-rekannya dan diakhiri dengan penyampaian semua materi kepada siswa (Huda 2014: 228). Berdasarkan penjelasan yang tealah dibahas diatas peneliti tertarik untuk menggunakan model student facilitator and explaining dan minat belajar untuk melihat pengaruh terhadap hasil belajar siswa.

\section{METODE}

Penelitian ini dilaksanakan di SMP Pembangunan Laboratorium UNP. Penelitian ini adalah penelitian kuantitatif dengan menggunakan metode penelitian eksperimen. Jenis penelitian eksperimen yang digunakan adalah eksperimen semu (quasi eksperimen). Penelitian ini dilakukan terhadap dua kelas yaitu kelas eksperimen dan kelas kontrol.Adapun desain yang digunakan adalah dengan desain faktorial $2 \times 2$. Berikut adalah tabel desain rancangan penelitian:

Tabel. 1 Rancangan penelitian

\begin{tabular}{|c|c|c|}
\hline \multirow{2}{*}{ Minat Belajar Siswa } & \multicolumn{2}{|c|}{ Model Pembelajaran } \\
\hline & $\begin{array}{l}\text { Model Student Fasilitator and } \\
\text { Eksplaining (A1) }\end{array}$ & $\begin{array}{l}\text { Model Konvensional } \\
\text { (A2) }\end{array}$ \\
\hline Tinggi (B1) & $\mathrm{A} 1 \mathrm{~B} 1$ & $\mathrm{~A} 2 \mathrm{~B} 1$ \\
\hline Rendah (B2) & $\mathrm{A} 1 \mathrm{~B} 2$ & $\mathrm{~A} 2 \mathrm{~B} 2$ \\
\hline
\end{tabular}

Penentuan kelas sampel baik kelas ekperimen dan kelas kontrol dilakukan dengan cara random (metodel acak), dimana dari 5 kelas yang ada dipilih 2 kelas yaitu kelas VIIC dan kelas VIIE. Hal ini dilandasi dengan pertimbangan karena kedua kelas ini memiliki kemampuan yang sama. 


\section{HASIL DAN PEMBAHASAN}

Berdasarkan hasil penelitian yang dilakukan, perhitungan untuk taraf kepercayaan $\alpha=0,05$ memperlihatkan bahwa hasil dari Lhitung keseluruhan kelompok lebih kecil dari nilai Ltabel. Hal ini dapat disimpulkan bahwa semua kelompok data, I, II, III, IV, V, VI, VII dan VIII berasar dari pupulasi yang berdistribusi normal. Lebih rinci hasil uji normalitas data, dapat dilihat pada tabel di bawah ini:

Tabel 2. Rekapitulasi Hasil Pengujian Normalitas Data

\begin{tabular}{ccccc}
\hline Kelompok & $\begin{array}{c}\text { Jumlah } \\
\text { Sampel }\end{array}$ & $\mathbf{L}_{\text {Hitung }}$ & $\mathbf{L}_{\text {Tabel }}$ & Kesimpulan \\
\hline I & 30 & 0,101 & 0,16 & Normal \\
II & 30 & 0,078 & 0,16 & Normal \\
III & 30 & 0,110 & 0,16 & Normal \\
IV & 30 & 0,09 & 0,16 & Normal \\
V & 15 & 0,159 & 0,22 & Normal \\
VI & 15 & 0,153 & 0,22 & Normal \\
VII & 15 & 0,094 & 0,22 & Normal \\
VIII & 15 & 0,153 & 0,22 & Normal \\
\hline
\end{tabular}

Uji homogenitas dalam penelitian ini menggunkan uji Bartlett yang dilakukan pada dua kelompok yaitu (a) dua kelompok data A1 dan A2 serta dua kelompok data B1 dan B2, (b) empat kelompok perlakuan yaitu A1B1, A1B2, A2B1, dan A2B2. Pengujiam homogenitas mengaju kepada pendekatan X2 dengan Ho diterima, jika X2 hitung < X2 tabel maka data homogen. Namun, Ho ditolak jika X2 hitung > X2 tabel maka data tidak homogen. Hasil perhitungan homogenitas pada masing-masing kelompok dirangkum dalam tabel dibawah ini

Tabel 3. Hasil Uji Homogenitas Varian Kelompok Data

\begin{tabular}{ccccccc}
\hline Kelompok & Varians Terpisah & Varians Gabungan & Harga B & $\mathbf{X}^{2} \mathbf{h}$ & $\mathbf{X}^{2} \mathbf{t}(\mathbf{0 . 9 5})(\mathbf{3})$ & Keterangan \\
\hline $\mathbf{A}_{\mathbf{1}}$ & 44,9 & & & & & \\
$\mathbf{A}_{\mathbf{2}}$ & 64,1 & 52,93 & 162,03 & 1,86 & 7,82 & Homogen \\
$\mathbf{B}_{\mathbf{1}}$ & 40,8 & & & & & \\
$\mathbf{B}_{\mathbf{2}}$ & 62,8 & & & & & \\
$\mathbf{A}_{\mathbf{1}} \mathbf{B}_{\mathbf{1}}$ & 31,4 & & & & & \\
$\mathbf{A}_{\mathbf{1}} \mathbf{B}_{\mathbf{2}}$ & 34,8 & 42,14 & 73,11 & 2,94 & 7,82 & Homogen \\
$\mathbf{A}_{\mathbf{2}} \mathbf{B}_{\mathbf{1}}$ & 31,6 & & & & & \\
$\mathbf{A}_{\mathbf{2}} \mathbf{B}_{\mathbf{2}}$ & 71,7 & & & & & \\
\hline
\end{tabular}

Dari kedua tabel diatas terlihat bahwa nilai X2 hitung dari kedua kelompok lebih kecil dari X2 tabel pada taraf kepercayaan $\alpha=0,05$. Maka, dari hal ini diseimpilkan bahwa keseluruhan kelompok memiliki varian yang homogen.

Hasil perhitungan normalitas dan homogenitas diatas menunjukkan bahwa populasi dari penelitian ini berasal dari populasi yang berdistribusi normal dan memiliki varian yang berdifat homogen. Maka bisa dilanjutkan untuk melakukan pengujian hipotesis yaitu dengan menggunakan analisa varian (ANAVA). Hasil dari uji hoptesis dijabarkan dalam tabel dibawah ini. 
Tabel 4. Hasil Uji ANAVA Dua Jalur

\begin{tabular}{|c|c|c|c|c|c|c|}
\hline Sumber Varians & JK & $\overline{d b}$ & RJK & $\mathbf{F}_{\text {hitung }}$ & $\mathbf{F}_{\text {tabel }}$ & $\overline{\text { Ket }}$ \\
\hline & & & & \multicolumn{3}{|c|}{$\mathrm{a}=0,05$} \\
\hline Model Pembelajaran (A) & 477,93 & 1 & 477,93 & 9,36 & 4.05 & Sig \\
\hline Minat (B) & 551,32 & 1 & 551,32 & 10,80 & 4.05 & Sig \\
\hline Inter AB & $-23,58$ & 1 & $-23,58$ & $-0,46$ & 4.05 & \\
\hline Kekeliruan Dalam & 2297,10 & 45 & 51,05 & - & - & \\
\hline Total & 3302,78 & 48 & & - & & \\
\hline
\end{tabular}

Adanya signifikannya pengaruh model pembelajaran dan minat belajar dalam analisia varian diatas. Sehingga untuk melihat rata-rata mana yang lebih tinggi diantara dua kelompok yang dipasangkan, maka dilanjutkan dengan uji Tukey.

Tabel 5. Hasil Uji Tukey antara Kelompok Data

\begin{tabular}{cccc}
\hline Kelompok Pembanding & Qh & Qt (= 0.05) & Keterangan \\
\hline $\mathbf{A}_{\mathbf{1}} \mathbf{B}_{\mathbf{1}}$ dan $\mathbf{A}_{\mathbf{2}} \mathbf{B}_{\mathbf{1}}$ & 3,46 & 2,92 & Signifikan \\
$\mathbf{A}_{\mathbf{1}} \mathbf{B}_{\mathbf{2}}$ dan $\mathbf{A}_{\mathbf{2}} \mathbf{B}_{\mathbf{2}}$ & 3,66 & 2,92 & Signifikan \\
\hline
\end{tabular}

Dari hasil pengujian hipotesis yang telah dialakukan bahwa hasil belajar IPS siswa memperlihatkan adanya perbedaan yang signifikan. Dari uji lanjut, memperlihatkan bahwa hasil belajar IPS siswa dengan menggunakan model pembelajaran student facilitator and explaining (SFE) lebih tinggi dibandingkan dengan model konvensional. Model pembelajaran SFE berpengaruh terhadap hasil belajar siswa, hal ini sejalan dengan penelitian yang dialkukan oleh Rianti (2017) bahwa model pembelajaran Student Facilitator and Explaining (SFE) seperti pendekatan inovatif lainya yang menekankan pada siswa belajar aktif memberikan hasil belajar yang lebih baik dari pembelajaran konvensional. Minat belajar siswa juga menunjukkan bahwa siswa dengan minat belajar yang tinggi mendapatkan hasil lebih tinggi nilai hasi belajar dibandingkan kelompok minat rendah. Hasil ini dipengaruhi oleh objektiftas dari penggunaan model student facilitator and explaining (SFE) itu sendiri. Model pembelajaran ini berpengaruh terhadap kelompok data.

Namun, sebaliknya, pengunaan model konvesional terhadap kelompok siswa yang memiliki minat rendah dan tinggi kurang berpengaruh terhadap hasil belajar hal ini terlihat rendahnya nilai yang didapat. Maka pembelajaran dengan model konfensional kurang berpengaruh terhdap hasil belajar, hal ini sejalan dengan apa yang disampaikan oleh mbelajaran konvensional dilakukan satu arah (Djafar, 2001:86), pembelajaran yang satu arah ini menjadikan siswa tidak aktif dalam proses pembelajaran serta menerima pengetahuan dari guru saja. Sejalan juga dengan apa yang disampaikan oleh Hamzah B. Uno dan Nurdin Mohamad (2012: 75) juga menjelaskan bahwa ketika pembelajaran berpusat pada guru dan siswa kurang aktif dalam proses pembelajaran. Akibatnya tingkat pemahaman siswa terhadap materi pembelajaran rendah. Penggunaan model pembelajaran student facilitator and explaining (SFE), berpengaruh terhadap kelompok yang memiliki minat belajar rendah dibandingkan dengan kelompok yang di terapkan dengan model konvensional.

\section{KESIMPULAN}

Bederdasarkan pengujian hipotesis berikut kesimpulan yang dapat ditarik dari hasil hasil penelitian: (1) secara keseluruhan, hasil belajar siswa dengan menggunakan model student facilitator and explaining (SFE), lebih tinggi dibandingkan dengan siswa yang diberi perlakuan model konvensional, (2) hasil belajar siswa yang memiliki minat tinggi dengan perlakuan model student fasilitator and eksplaining (SFE) lebih tinggi dibandingkan dengan kelompok siswa minat belajar rendah yang diterapkan dengan model konvensioan, (3) hasil belajar siswa kelompok minat belajar rendah dengan penerapan model student facilitator and explaining (SFE) lebih tinggi dibandingkan kelompok siswa berminat rendah dengan perlakuan model konvensional, (4) tidak terdapat interaksi antara model pembelajaran student facilitator and explaining (SFE) dan model konvensioan dengan minat belajar (tinggi dan rendah) terhadap hasil belajar mata pelajaran IPS siswa. 


\section{DAFTAR RUJUKAN}

Djaafar. (2001). Kontribusi Strategi Pembelajaran Terhadap Hasil Belajar. Jakarta: Depdiknas

Huda, M. (2014). Model-model Pengajaran dan Pembelajaran: isu-isu Metodis dan Paradigmatis. Yogyakarta: Pustaka Pelajar.

Rianti, L., \& Nulhakim, L. (2017). Pengaruh Model Student Fasilitator and Eksplaining (SFAE) Terhadap Pemahaman Konsep Siswa Kelas IV Pada Mata Pelajaran IPA. Jurnal Pendidikan Guru Sekolah Dasar, 3, 64-73.

Rusman. (2011). Model-model Pembelajaran: Mengembangkan Potensi Guru. Jakarta: PT Grafindo Persada.

Slameto. (2010). Belajar dan Faktor-Faktor Yang Mempengaruhi. Jakarta: Rineka Cipta.

Sudjana, N. (2009). Penilaian Hasil Proses Belajar Mengajar. Bandung: PT Remaja Rosdakarya.

Syah, M. (2005). Psikologi Belajar.Jakarta PT Raja Grafindo.

Uno, H. B., \& Mohammad, N. (2012). Belajar dengan pendekatan PALKEM. Jakarta: Bumi Aksara.

Wirdawati. (2017). Modul Pengembangan Keprofesian Berkelanjutan Mata Pelajaran Ilmu Pengetahuan Sosial (IPS) Sekolah Menengah Pertama (SMP)Terintegrasi Penguatan Pendidikan Karakter dan Pengembangan Sosial. Jakarta: Kementrian Pendidikan dan Kebudayaan Direktorat Jendral Guru dan Tenaga Kependidikan. 